\title{
Clinical Relevance of Botulinum Toxin Immunogenicity
}

\author{
Reiner Benecke
}

Department of Neurology, University of Rostock, Rostock, Germany

\section{Abstract}

Botulinum toxin type $\mathrm{A}$ is a $150 \mathrm{kD}$ protein produced by Clostridium botulinum, which exists in a complex with up to six additional proteins. The ability of botulinum toxin to inhibit acetylcholine release at the neuromuscular junction has been exploited for use in medical conditions characterized by muscle hyperactivity. As such, botulinum toxin is widely recommended by international treatment guidelines for movement disorders and it has a plethora of other clinical and cosmetic indications. The chronic nature of these conditions requires repeated injections of botulinum toxin, usually every few months. Multiple injections can lead to secondary treatment failure in some patients that may be associated with the production of neutralizing antibodies directed specifically against the neurotoxin. However, the presence of such antibodies does not always render patients non-responsive. The reported prevalence of immunoresistance varies greatly, depending on factors such as study design and treated indication. This review presents what is currently known about the immunogenicity of botulinum toxin and how this impacts upon patient nonresponse to treatment. The complexing proteins may act as adjuvants and stimulate the immune response. Their role and that of neutralizing and non-neutralizing antibodies in the response to botulinum toxin is discussed, together with an assessment of current neutralizing antibody measurement techniques. Botulinum toxin preparations with different compositions and excipients have been developed. The major commercially available preparations of botulinum toxin are Botox ${ }^{\circledR}$ (onabotulinumtoxinA; Allergan, Inc., Ireland), Dysport ${ }^{\circledR}$ (abobotulinumtoxinA; Ipsen Ltd, UK), and Xeomin ${ }^{\circledR}$ (incobotulinumtoxinA; botulinum toxin type A [150 kD], free from complexing proteins; NT 201; Merz Pharmaceuticals $\mathrm{GmbH}$, Germany). The new preparations of botulinum toxin aim to minimize the risk of immunoresistance in patients being treated for chronic clinical conditions.

\section{Introduction}

The anaerobic, spore-forming, rod-shaped bacterium, Clostridium botulinum, produces the botulinum toxin, which causes botulism after ingestion. The botulinum toxin complex contains a $150 \mathrm{kD}$ neurotoxin together with a complex of up to six additional proteins. The neurotoxin is cleaved by clostridial proteases into a heavy chain $(\sim 100 \mathrm{kD})$, which binds to gangliosides and a protein receptor on pre-synaptic nerve endings, and a light chain $(\sim 50 \mathrm{kD})$, which blocks the release of the neurotransmitter acetylcholine, causing dose-dependent weakening of the target muscle.

There are seven immunologically distinct serotypes of botulinum toxin (A to $G$ ), of which types $A$ and $B$ are used clinically. The latest commercially available botulinum neurotoxin type A is $\mathrm{Xeomin}^{\circledR}$ (incobotulinumtoxinA; botulinum toxin type A [150 kD], free from complexing proteins; NT 201; Merz Pharmaceuticals GmbH, Germany). Botulinum toxin type A is also marketed as Botox ${ }^{\circledR}$ (onabotulinumtoxinA; Allergan, Inc., Ireland), Dysport ${ }^{\circledR}$ (abobotulinumtoxinA; Ipsen Ltd, UK) and there are also Chinese formulations not described here. There are differences between the botulinum toxin drug substances, such as the bacterial strains from which they are produced, the manufacturing processes, and the type or quantity of excipients contained in each formulation. Currently, the only botulinum toxin type B product available is Myobloc ${ }^{\circledR}$ (rimabotulinumtoxinB; Solstice Neurosciences Inc., USA; also called Neurobloc ${ }^{\circledR}$; Eisai Europe Ltd, UK in some countries).

Botulinum toxin was first used clinically in the late 1970s in ophthalmology to treat strabismus, ${ }^{[1]}$ and over the last 20 years 
has gained widespread use in conditions requiring inhibition of excessive muscle spasm. The broad range of medical indications for botulinum toxin include treatment of movement disorders (e.g. spasticity, cervical dystonia), urological disorders (e.g. overactive bladder), dermatological conditions (e.g. axillary hyperhidrosis), as well as cosmetic applications. As the indicated clinical conditions are chronic in nature and the botulinum toxin effects typically last no more than several months, patients have to be injected repeatedly to maintain symptom control.

The European Federation of Neurological Societies (EFNS) dystonia guidelines recommend botulinum toxin type A as firstline treatment for primary cranial (excluding oromandibular) or cervical dystonia, and state that it is also effective for writing dystonia. ${ }^{[2]}$ Botulinum toxin type $\mathrm{B}$ can be used if there is resistance to type $A \cdot{ }^{[3]}$ An evidence-based systematic review by the American Academy of Neurology (AAN) states that botulinum toxin injections should be offered as a treatment option for cervical dystonia and may be offered for blepharospasm, focal upper extremity dystonia, adductor laryngeal dystonia, and upper extremity tremor. ${ }^{[4]}$ A lower level of evidence was detected for hemifacial spasm, focal lower limb dystonia, and motor tics. Another AAN evidence-based systematic review recommends botulinum toxin for the treatment of spasticity in adults and children with the strongest evidence (level A). ${ }^{[5]}$

Botulinum toxin is regarded as foreign by the host and therefore has the potential to induce an immune response, particularly with repeated administration, which can lead to secondary treatment failure. This review will discuss the response to botulinum toxin over time, including current understanding of the immunogenicity of botulinum toxin and its clinical implications.

\section{Patient Non-Responsiveness to Treatment}

Many patients respond well to treatment with botulinum toxin but, for a variety of reasons, some patients do not. ${ }^{[6]}$ Nonresponse can be defined as a lack of patient (subjective) or physician (objective) satisfaction with the therapeutic outcome of a drug. It may be transient, in which one application of the treatment is not efficacious but subsequent applications are, or permanent, such that neither the first nor subsequent applications produce the desired clinical effect. Similarly, there may be only a partial lack of response (some therapeutic aspects are not achieved) or a complete lack of response (no therapeutic or side effects can be detected).

Primary non-response refers to a lack of response to treatment from the first application. It may occur in patients with pseudo-dystonia, or those with a clinical subtype that has reduced sensitivity to botulinum toxin, such as anterocollis in cervical dystonia, and sensory blepharospasm. ${ }^{[6]}$ Misdiagnosis is another important cause of primary non-response. For example, myasthenia gravis is not treated by botulinum toxin, but the first noticeable symptom is often weakness of the eye muscles, ${ }^{[7]}$ and so it may be mistaken for blepharospasm (for which botulinum toxin treatment is indicated). ${ }^{[6]}$ Inadequate dosing, handling errors during drug storage or preparation, or problems with drug administration (e.g. an inaccessible muscle or injection into the wrong muscle) can also cause either a primary or secondary non-response. ${ }^{[6]}$

Secondary non-response occurs during the course of therapy when a previously effective treatment no longer produces clinical benefit. This is often subjectively described and influenced by a patient's expectation. Sometimes there may be a placebo effect of the first series of treatment, or the patients return for a re-injection before they have returned to baseline. Other patient factors also have an effect, as some disorders worsen over time and can be exacerbated by stress. In addition, the despondency caused by a chronic debilitating condition can result in symptom deterioration such that a previously efficacious dose induces a subclinical response. ${ }^{[6]}$

An important reason for secondary treatment failure of any therapeutic protein is its neutralization by antibodies; even proteins with an identical sequence to the human protein can be immunogenic. ${ }^{[8]}$ The clinical effect may wane gradually, eventually leading to complete treatment failure. In one study of 27 patients with complete treatment failure due to neutralizing antibodies, the majority $(81 \%)$ of patients had previously experienced partial antibody-induced treatment failure. ${ }^{[9]}$ Most patients in this study developed complete treatment failure within 40 months of starting botulinum toxin treatment (figure 1).

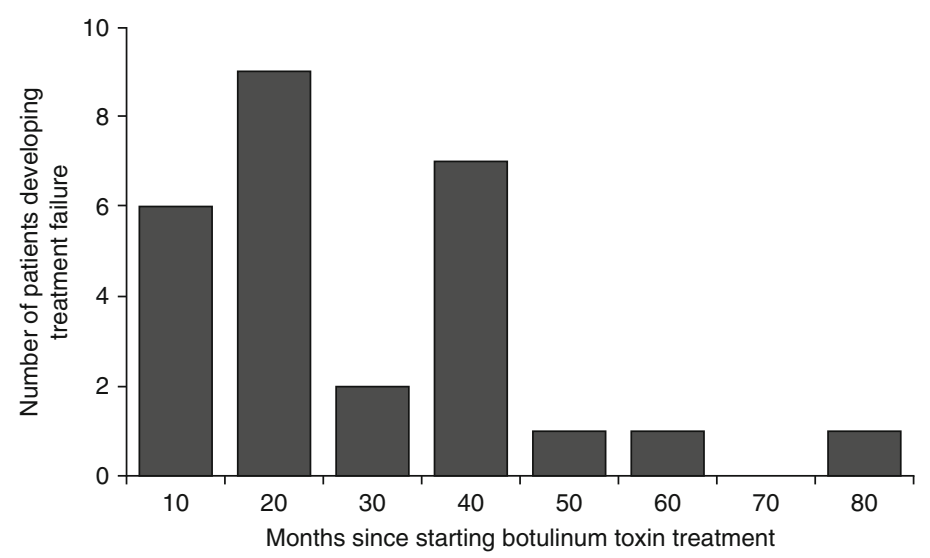

Fig. 1. Histogram showing latencies between the initiation of botulinum toxin therapy and the occurrence of complete antibody-induced therapy failure in a study of 27 patients. ${ }^{[9]}$ 


\section{Neutralizing and Non-neutralizing Antibodies}

Native botulinum toxin is a complex of the $150 \mathrm{kD}$ neurotoxin and other non-toxic clostridial proteins, including hemagglutinins. All of these foreign proteins are antigens and have the potential to induce an immune response, but only the neurotoxin component has a therapeutic effect. Antibodies that block its pharmacological effects are termed neutralizing or blocking antibodies. The non-toxic clostridial proteins, collectively referred to as complexing proteins or neurotoxin-associated proteins (NAPs), protect the neurotoxin against degradation in the acidic conditions of the host gastrointestinal tract (particularly in the stomach). ${ }^{[10]}$ Under physiological $\mathrm{pH}$ conditions, the complexing proteins dissociate almost completely from the neurotoxin following constitution with saline and even before injection into the target tissue. ${ }^{[11]}$ Therefore, complexing proteins are not expected to improve clinical outcome in therapeutic use of botulinum toxin, and specific antibodies generated against the complexing proteins are termed non-neutralizing. However, complexing proteins increase the bacterial protein load and can potentially increase the immunogenic risk of neutralizing antibody formation.

In a mouse study, the production of antibodies was increased with botulinum toxin type B in a large toxoid complex compared with the neurotoxoid alone. ${ }^{[12]}$ The presence of the complexing proteins was associated with adjuvant activity via the interleukin- 6 cytokine pathway. Another preclinical study showed that the botulinum neurotoxoid type A with complexing proteins triggered a stronger immune response than the purified $150 \mathrm{kD}$ neurotoxoid alone. ${ }^{[13]}$ This study reported that hemagglutinin Hn-33 exhibited stronger immunogenicity than the purified neurotoxoid type A. As Hn-33 is the largest component of the complexing proteins, this result indicated that $\mathrm{Hn}-33$ is the most immunogenic component of the botulinum toxin type $\mathrm{A}$ complex. These studies utilized formaldehyde-inactivated toxoids rather than native proteins, which will have affected their immunogenicity, ${ }^{[13,14]}$ and it has been noted that some of the methods used in the mouse study ${ }^{[12]}$ may differ from the use of botulinum toxin in therapeutic applications. ${ }^{[14]}$ Although further investigations are needed, these studies revealed that the toxoid complex is more immunogenic than the purified neurotoxoid. The immunogenicity of toxoid components is of relevance since toxoid components (i.e. inactive neurotoxin albeit not through formaldehyde inactivation) are contained in some commercial botulinum toxin products. ${ }^{[15]}$ It has therefore been proposed that reducing the foreign protein load of botulinum toxin by removal of the complexing proteins would help to reduce the formation of neutralizing antibodies, without affecting therapeutic efficacy. The use of purified neurotoxin preparations could potentially reduce the rate of secondary treatment failure.

The role of complexing proteins has been further investigated in a recent in vitro study of the binding properties of the type A neurotoxin complex. The neurotoxin alone did not interact with non-neuronal cell types, but the complexing proteins (both alone and in complex with the neurotoxin) were shown to bind to neuroblasts, lymphoblasts, skeletal muscle cells, and skin fibroblasts. ${ }^{[16]}$ These findings raise the possibility that other, as yet unconfirmed, detrimental effects of complexing proteins may occur in host tissues, which may not directly influence the neurotoxin mechanism of action, but instead have an indirect effect similar to the adjuvant stimulation of neutralizing antibodies that block the clinical effects of the neurotoxin.

\section{Attempts to Overcome Antibody-Induced Treatment Failure}

Attempts to overcome the effects of antibody-induced treatment failure have had limited success. Massively increased botulinum toxin doses cannot overcome complete antibodyinduced treatment failure, although it has been suggested that perhaps this may be effective in partial treatment failure. ${ }^{[6]}$ However, this strategy is simply expected to exacerbate the problem because the antibody response will increase when the antigen dose is increased. ${ }^{[17]}$

The use of different botulinum toxin serotypes has also been investigated; an initial study of botulinum toxin type B demonstrated efficacy for the treatment of patients with type A-resistant cervical dystonia. ${ }^{[18]}$ However, in a later study, botulinum toxin type B appeared to be only temporarily effective in most patients with type A resistance. ${ }^{[19]}$ Patients may respond to the alternate serotype but eventually experience treatment failure due to the development of antibodies against the second botulinum toxin. These patients may also be primed to develop antibodies to the second serotype due to crossreactivity between the first and second toxins. ${ }^{[17]}$ Therefore, once a patient has produced neutralizing antibodies against one serotype, switching to another is unlikely to produce a clinical response because immunoresistance to the second serotype will develop swiftly. Prior resistance to botulinum toxin type A has been shown to be an important risk factor for the development of anti-botulinum toxin type B antibodies. ${ }^{[20]}$ Clinical evidence suggests that botulinum toxin type $\mathrm{B}$ has low specific biological activity and is more immunogenic than botulinum toxin type $\mathrm{A}$, inducing secondary treatment failure after only a few injections, ${ }^{[20-22]}$ although it should be noted that botulinum toxin 
type B is applied in a markedly higher dose (higher protein load), which might be the reason for antibody production. The preferred approach is to prevent the formation of neutralizing antibodies in the first place.

\section{Clinical Relevance of Antibodies}

Neutralizing antibodies against the botulinum toxin may lead to issues with efficacy, and ultimately treatment failure as described above. Antigenicity is generally proportional to protein load, and a higher protein load per dose of botulinum toxin has been identified as a risk factor for increased antibody titer. ${ }^{[20,23-25]}$ This has been illustrated by the 5 -fold reduction in protein load within the current onabotulinumtoxinA type compared with the original preparation, which has corresponded with a reduced incidence of neutralizing antibodies. Previous studies reported that up to $17 \%$ of patients with cervical dystonia treated with the original onabotulinumtoxinA preparation had neutralizing antibodies. ${ }^{[26,27]}$ A database review of patients with cervical dystonia from a single clinic reported that neutralizing antibodies were detected in four $(9.5 \%)$ out of 42 patients who received the original preparation (100 U/25 ng protein) versus none of 119 patients using the newer product (100 U/5 ng protein). ${ }^{[26]}$ The authors concluded that this was related to the lower protein load. ${ }^{[26]}$

IncobotulinumtoxinA is a botulinum neurotoxin product that does not contain complexing proteins. ${ }^{[15,28-30]}$ Initial experiments indicate that the minimized total protein load results in reduced immunogenic potential. Repeated intramuscular administration of high-dose incobotulinumtoxinA (up to $16 \mathrm{U} / \mathrm{kg}$ bodyweight) to cynomolgus monkeys did not induce detectable levels of neutralizing antibodies even when administered every 4 weeks for 4 months. ${ }^{[31]}$ Similarly, in a rabbit model, the development of neutralizing antibodies was observed with abobotulinumtoxinA and onabotulinumtoxinA, but not with incobotulinumtoxinA, even when administered at doses up to five times greater than those recommended for clinical use. ${ }^{[32]}$ IncobotulinumtoxinA has a low protein content, but a high specific activity, and retains clinical efficacy and safety profiles equivalent to conventional botulinum toxin type A formulations. ${ }^{[15,33]}$ In contrast to conventional formulations, incobotulinumtoxinA contains the pure $150 \mathrm{kD}$ neurotoxin, free from complexing protein, and thus has a low foreign protein content. The amount of foreign protein content administered is considered as one of the factors for secondary treatment failure. ${ }^{[34]}$

Recent peer-reviewed publications and presentations of current botulinum toxin formulations containing complexing proteins in long-term studies in cervical dystonia or spasticity have reported neutralizing antibodies in up to $6.6 \%$ of patients. ${ }^{[35-40]}$ It should be noted that no controlled, long-term studies have compared the immunogenicity of different botulinum toxin products. Variability in the reported prevalence of neutralizing antibodies could be related to factors such as indication, administered dosages, assay methods, timing of serum sample testing, whether or not patients had previously received botulinum toxin therapy, and duration of treatment. [36]

Studies of botulinum toxin type A containing complexing proteins suggest that, in addition to an increased protein load, a higher dosing frequency and greater number of injections (and the use of booster injections 2-3 weeks after original injections) may also increase the risk of neutralizing antibodies. ${ }^{[6,41,42]}$ Higher rates of neutralizing antibodies have also been reported in pediatric patients (approximately 30\% of patients) who were prescribed current botulinum toxin type A formulations. ${ }^{[42,43]}$ This may be an age-related feature of the immune response ${ }^{[44]}$ or a dose-related effect, as suggested by the authors of one of these pediatric studies, due to the higher dose per kilogram body weight in this age group. ${ }^{[42]} \mathrm{A}$ study of botulinum toxin type $\mathrm{A}$ in patients with urologic disorders (hyperactive detrusor or sphincter dysfunction) has reported the presence of antibodies against botulinum toxin in a higher proportion of patients (4/25 patients; $16 \%)$ than observed in cervical dystonia. ${ }^{[45]}$ The authors speculate that this may be because the urinary bladder (with its urothelium) is an immunoreactive organ that responds, for example, to urinary tract infections, which may also sensitize bladders to other antigens.

A waning clinical response to botulinum toxin over several injection sessions is generally the trigger to investigate whether neutralizing antibodies are being produced. However, immune responses can differ between patients, and the reduced clinical response could also be caused by either acute or delayed reactions such as hypersensitivity or the formation of immune complexes. ${ }^{[44]}$ Although it is important to detect the presence of neutralizing antibodies, their clinical impact should also be determined as they do not always lead to treatment failure, and thus antibody titers may occur at a subclinical level. ${ }^{[20,40,46,47]}$ Determining the true clinical impact of neutralizing antibodies in patients treated with botulinum toxin is complicated by the limitations of antibody measurement techniques and inter-clinic variability regarding the definition of secondary non-responsiveness. ${ }^{[22]}$

\section{Neutralizing Antibody Measurement Techniques}

If neutralizing antibody production is suspected because the clinical effects of botulinum toxin decline and other causes of 


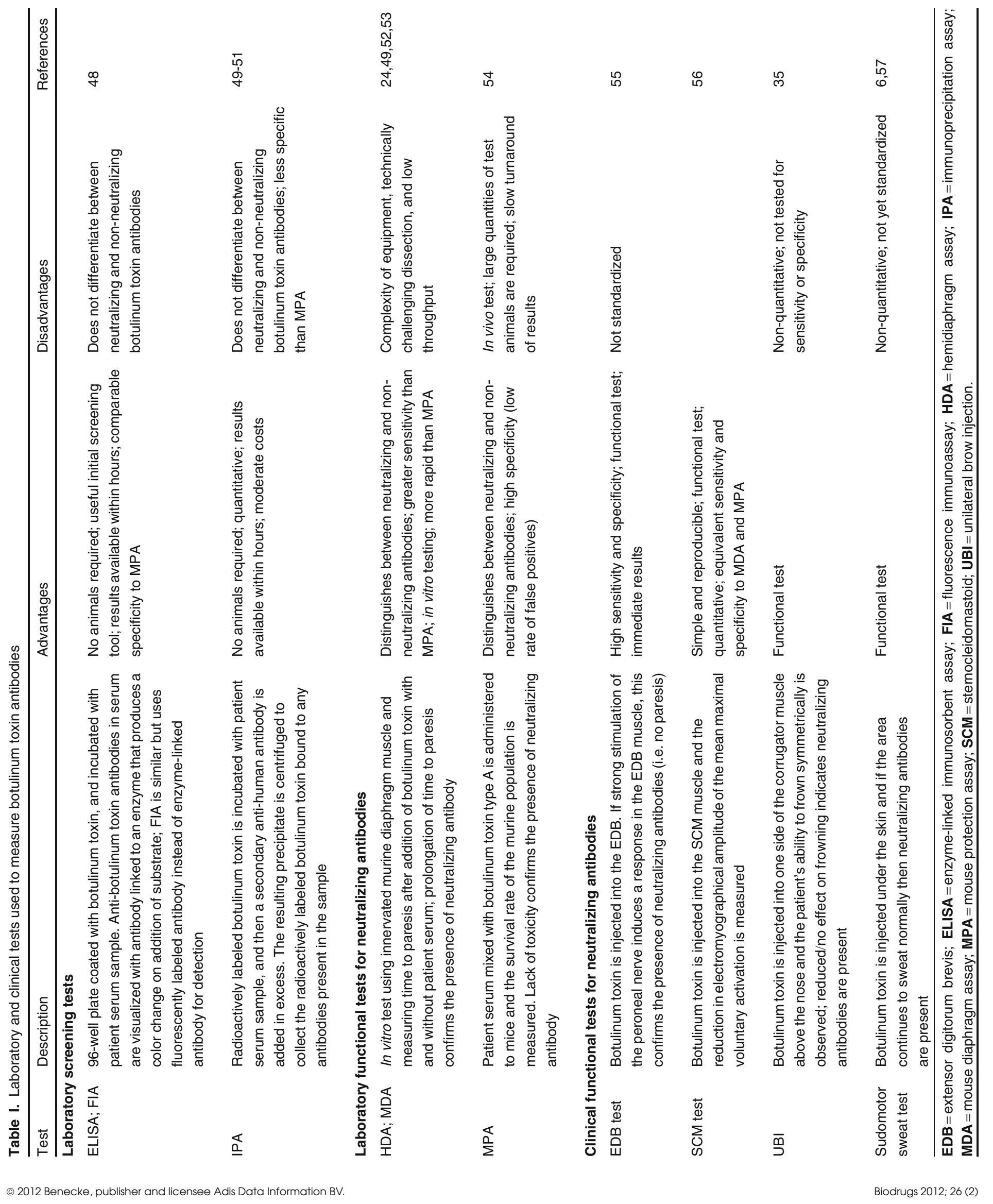


treatment failure have been excluded, biochemical and/or functional tests can be employed to detect antibodies against botulinum toxin (table I).

Enzyme-linked immunosorbent assay (ELISA) and fluorescence immunoassay (FIA) tests are useful first screening tools, and the immunoprecipitation assay (IPA) is also used. However, these laboratory screening tests are not able to distinguish between neutralizing and non-neutralizing antibodies. The hemidiaphragm assay (HDA) and the mouse protection assay (MPA) are so far the only available laboratory functional assays for the detection of neutralizing antibodies, and provide good sensitivity. However, a key disadvantage of the MPA is that in vivo animal testing is needed. The HDA test has higher sensitivity than MPA and this may result in detection of subclinical antibody titers that do not result in treatment failure. Therefore, in clinical practice, a clinical test should also be included to evaluate cases of antibody-induced treatment failure. Functional assessments performed directly on the individual patient in the clinic yield results within days or weeks. They include the extensor digitorum brevis (EDB) test, the unilateral brow injection (UBI) test, the sternocleidomastoid (SCM) test, and the sudomotor sweat test. ${ }^{[6,35,55,57]}$

\section{Botulinum Toxin Products}

Botulinum toxin products vary considerably in pharmaceutical composition (table II). These different physicochemical properties, coupled with the lack of standardization for measuring their potency (i.e. biological activity; expressed in U/ng protein, in which $1 \mathrm{U}$ is the lethal dose in $50 \%$ of mice tested $\left.\left[\mathrm{LD}_{50}\right]\right),{ }^{[15]}$ means that the dosage cannot simply be interchanged between brands. ${ }^{[5]}$ Reports of the effective botulinum toxin type A clinical conversion ratios (i.e. $\mathrm{U}$ of Product $\mathrm{X}$ producing a similar clinical effect to $\mathrm{U}$ of Product $\mathrm{Y}$ ) vary considerably in the literature, ranging up to $11: 1 \mathrm{U}$ for abobotulinumtoxinA: onabotulinumtoxin $\mathrm{A},{ }^{[65,66]}$ although it is generally agreed that there is a $1: 1 \mathrm{U}$ dose conversion rate between onabotulinumtoxinA and incobotulinumtoxinA. ${ }^{[32,67-69]}$

Recently, Frever ${ }^{[15]}$ sought to compare the neurotoxin content of each agent with a new and more sensitive ELISA, and found that $100 \mathrm{U}$ of onabotulinumtoxinA, abobotulinumtoxinA, and incobotulinumtoxinA contained $0.73 \mathrm{ng}, 0.65 \mathrm{ng}$, and $0.44 \mathrm{ng}$ of neurotoxin, respectively (table II; figure 2). Calculations based on these data showed that the highest specific neurotoxin activity was found in incobotulinumtoxinA ( $227 \mathrm{U} / \mathrm{ng}$ ), followed by abobotulinumtoxinA (154 U/ng) and onabotulinumtoxinA (137 U/ng). As incobotulinumtoxinA and onabotulinumtoxinA have demonstrated similar clinical activity,

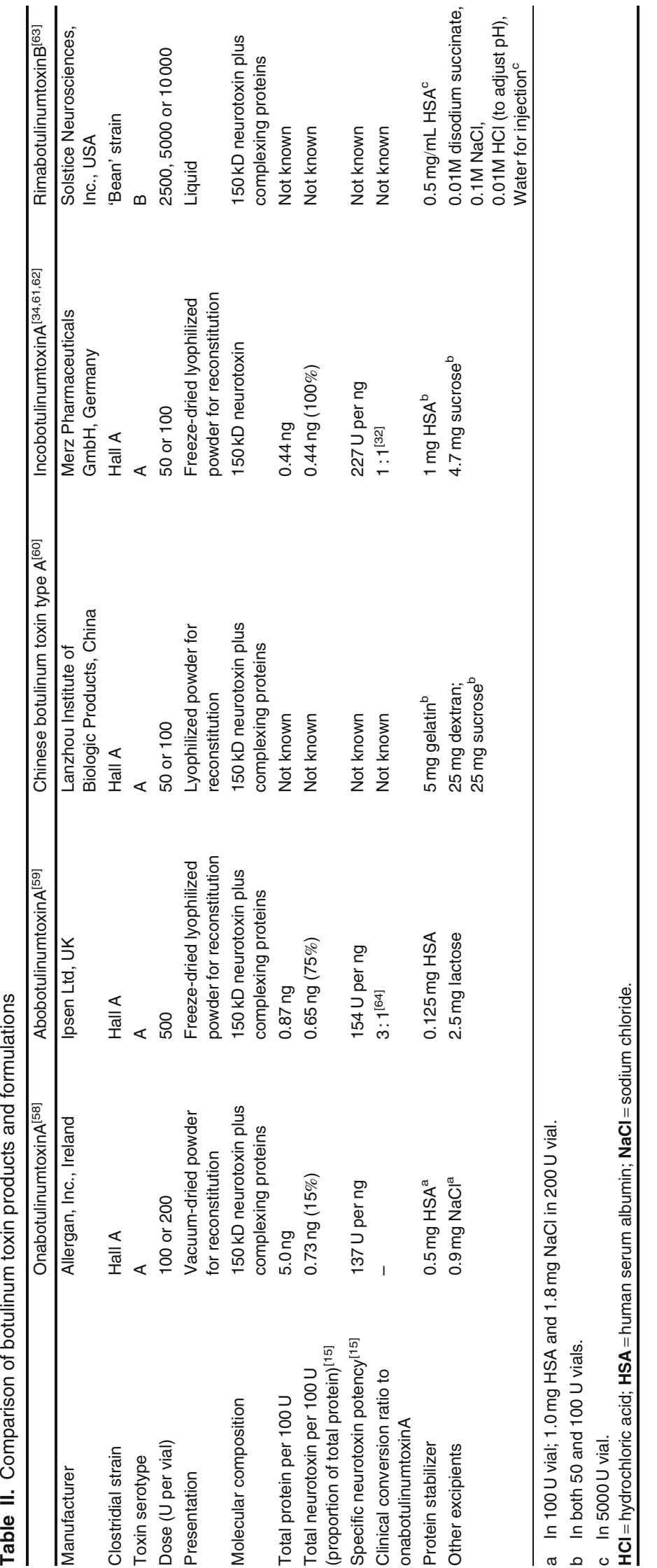




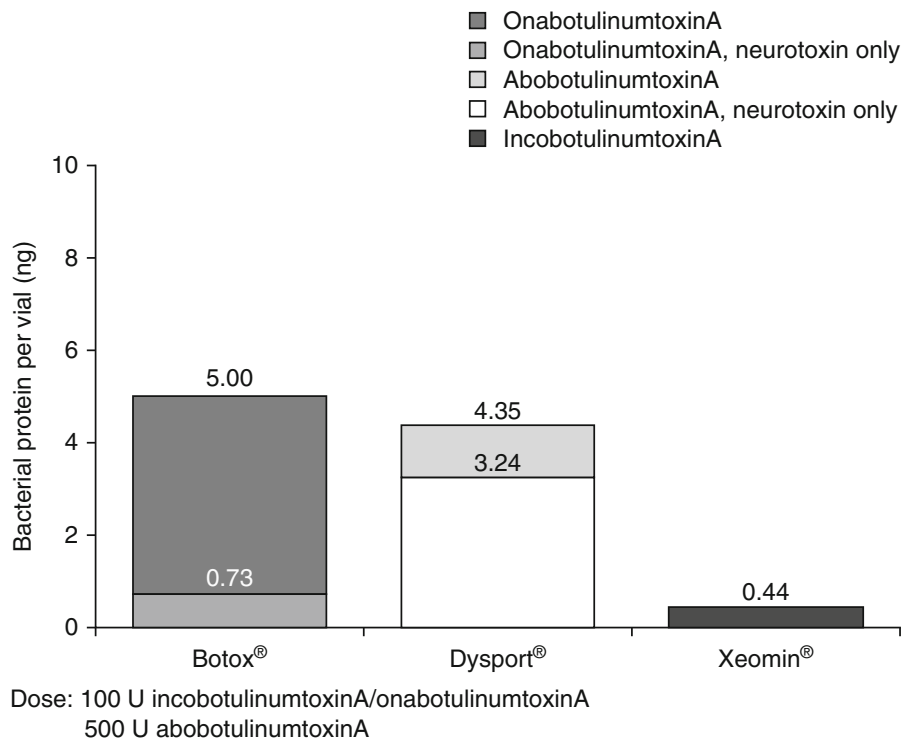

Fig. 2. Total bacterial protein and neurotoxin content of botulinum toxin type $A$ products. Mean concentrations of botulinum neurotoxin type $A$ in onabotulinumtoxinA, incobotulinumtoxinA, and abobotulinumtoxinA were analyzed by a sensitive sandwich ELISA. ${ }^{[15]}$

these findings suggest that $0.44 \mathrm{ng}$ of incobotulinumtoxinA neurotoxin has the same biological activity as $0.73 \mathrm{ng}$ of onabotulinumtoxinA neurotoxin, and the authors therefore concluded that some of the $150 \mathrm{kD}$ neurotoxin in onabotulinumtoxin $\mathrm{A}$ is likely to be inactive (possibly denatured), adding further protein load in addition to the complexing proteins to the injected dose $^{[15]}$ OnabotulinumtoxinA is unique among the botulinum toxin type A formulations in that it is vacuum dried by a process involving sodium chloride, which may have a detrimental effect on neurotoxin activity ${ }^{[28]}$ and may be responsible for its higher toxoid (inactive neurotoxin) content. ${ }^{[15]}$ This additional amount of inactive/denatured protein could increase the production of neutralizing antibodies against the onabotulinumtoxinA neurotoxin, leading to a greater risk of therapeutic failure. In contrast, incobotulinumtoxinA has a low neurotoxin (and overall protein) content but retains a high biological potency, so a comparatively small amount of protein confers clinical benefit while potentially carrying a lower risk of stimulating the patient's immune system. ${ }^{[15]}$ There has been discussion that the units of each botulinum product are not interchangeable due to differences in in-house $\mathrm{LD}_{50}$ protocols, which result in differences in the potencies reported, and hence bias in the specific activities that were calculated. ${ }^{[70,71]}$ However, the potency assay demonstrates the same number of units for onabotulinumtoxin $\mathrm{A}$ and incobotulinumtoxinA, as reported in the product label. ${ }^{[34,71]}$ Moreover, several clinical studies have reported clear equipotency for these agents. ${ }^{[67,68,72]}$

\section{Conclusions}

Development of neutralizing antibodies against botulinum neurotoxin is often the reason for secondary treatment failure. The presence of complexing proteins within botulinum neurotoxin agents increases the protein load and may exacerbate an immune response. Further studies investigating the long-term immunological effects of different botulinum toxin products are required, and it may be helpful to develop a consensus approach to schedules and techniques for antibody testing, as well as a more precise definition of what constitutes treatment failure. Better understanding of the possible immunological influence of the manufacturing techniques and constituents used in different botulinum toxin formulations is also needed. In the interim, physicians must use their clinical experience to decide how and when to treat their patients in order to minimize the risk of immunoresistance.

\section{Acknowledgments}

Professor Benecke has worked as a consultant for Merz Pharmaceuticals GmbH.

The author would like to thank Helen Nivison, $\mathrm{PhD}$, and Emma Robinson, from Complete Medical Communications, who provided medical writing assistance funded by Merz Pharmaceuticals GmbH.

\section{References}

1. Scott AB. Botulinum toxin injection into extraocular muscles as an alternative to strabismus surgery. J Pediatr Ophthalmol Strabismus 1980; 17: 21-5

2. Albanese A, Asmus F, Bhatia KP, et al. EFNS guidelines on diagnosis and treatment of primary dystonias. Eur J Neurol 2011; 18: 5-18

3. Novak I, Campbell L, Boyce M, et al. Botulinum toxin assessment, intervention and aftercare for cervical dystonia and other causes of hypertonia of the neck: international consensus statement. Eur J Neurol 2010; 17 Suppl. 2: 94-108

4. Simpson DM, Blitzer A, Brashear A, et al. Assessment: Botulinum neurotoxin for the treatment of movement disorders (an evidence-based review): report of the Therapeutics and Technology Assessment Subcommittee of the American Academy of Neurology. Neurology 2008; 70: 1699-706

5. Simpson DM, Gracies JM, Graham HK, et al. Assessment: Botulinum neurotoxin for the treatment of spasticity (an evidence-based review): report of the Therapeutics and Technology Assessment Subcommittee of the American Academy of Neurology. Neurology 2008; 70: 1691-8

6. Dressler D. Clinical presentation and management of antibody-induced failure of botulinum toxin therapy. Mov Disord 2004; 19 Suppl. 8: S92-100

7. National Institute of Neurological Disorders and Stroke (NINDS), National Institutes of Health. Myasthenia gravis fact sheet [online]. Available from URL: http://www.ninds.nih.gov/disorders/myasthenia_gravis/detail_myas thenia_gravis.htm [Accessed 2011 Jan 26]

8. Kromminga A, Schellekens H. Antibodies against erythropoietin and other proteinbased therapeutics: an overview. Ann N Y Acad Sci 2005; 1050: 257-65

9. Dressler D. Clinical features of antibody-induced complete secondary failure of botulinum toxin therapy. Eur Neurol 2002; 48: 26-9

10. Sharma SK, Fu FN, Singh BR. Molecular properties of a hemagglutinin purified from type A Clostridium botulinum. J Protein Chem 1999; 18: 29-38 
11. Eisele KH, Fink K, Vey M, et al. Studies on the dissociation of botulinum neurotoxin type A complexes. Toxicon 2011; 57: 555-65

12. Lee J-C, Yokota K, Arimitsu H, et al. Production of anti-neurotoxin antibody is enhanced by two subcomponents, HA1 and HA3b, of Clostridium botulinum type B 16S toxin-haemagglutinin. Microbiology 2005; 151: 3739-47

13. Kukreja R, Chang T-W, Cai S, et al. Immunological characterization of the subunits of type A botulinum neurotoxin and different components of its associated proteins. Toxicon 2009; 53: 616-24

14. Atassi MZ. On the enhancement of anti-neurotoxin antibody production by subcomponents HA1 and HA3b of Clostridium botulinum type B $16 \mathrm{~S}$ toxinhaemagglutinin. Microbiology 2006; 152: 1891-5

15. Frevert J. Content of botulinum neurotoxin in Botox ${ }^{\circledR} /$ Vistabel $^{\circledR}$, Dysport ${ }^{\circledR /}$ Azzalure ${ }^{\circledR}$, and Xeomin ${ }^{\circledR} /$ Bocouture $^{\circledR}$. Drugs R D 2010; 10: 67-73

16. Sun Y, Wang L, Singh BR. Botulinum neurotoxin type A complex proteins bind to neuronal as well as non-neuronal cells [poster]. 14th International Congress of Parkinson's Disease and Movement Disorders; 2010 Jun 13-17; Buenos Aires, Argentina

17. Atassi MZ. Basic immunological aspects of botulinum toxin therapy. Mov Disord 2004; 19 Suppl. 8: S68-84

18. Brin MF, Lew MF, Adler CH, et al. Safety and efficacy of NeuroBloc (botulinum toxin type B) in type A-resistant cervical dystonia. Neurology 1999; 53: 1431-8

19. Dressler D, Bigalke H, Benecke R. Botulinum toxin type B in antibody-induced botulinum toxin type A therapy failure. J Neurol 2003; 250: 967-9

20. Jankovic J. Botulinum toxin therapy for cervical dystonia. Neurotox Res 2006; 9: $145-8$

21. Dressler D, Hallett M. Immunological aspects of Botox, Dysport and Myobloc/ NeuroBloc. Eur J Neurol 2006; 13 Suppl. 1: 11-5

22. Kamm C, Benecke R. Individualized management of cervical dystonia with different serotypes of botulinum toxin: recent therapeutic advances and risk development of neutralizing antibodies. Eur Neurol J 2010; 2: 49-54

23. Borodic G, Johnson E, Goodnough M, et al. Botulinum toxin therapy, immunologic resistance, and problems with available materials. Neurology 1996; 46: 26-9

24. Göschel H, Wohlfarth K, Frevert J, et al. Botulinum A toxin therapy: neutralizing and nonneutralizing antibodies - therapeutic consequences. Exp Neurol 1997; 147: 96-102

25. Wenzel RG. Pharmacology of botulinum neurotoxin serotype A. Am J Health Syst Pharm 2004; 61 Suppl. 6: S5-10

26. Jankovic J, Vuong KD, Ahsan J. Comparison of efficacy and immunogenicity of original versus current botulinum toxin in cervical dystonia. Neurology 2003; 60: 1186-8

27. Mejia NI, Vuong KD, Jankovic J. Long-term botulinum toxin efficacy, safety, and immunogenicity. Mov Disord 2005; 20: 592-7

28. Bigalke H. Properties of pharmaceutical products of botulinum neurotoxins. In: Jankovic J, Albanese A, Atassi MZ, et al., editors. Botulinum toxin: therapeutic clinical practice and science. Philadelphia (PA): Saunders Elsevier, 2009: 389-97

29. Frevert J. Xeomin is free from complexing proteins. Toxicon 2009; 54: 697-701

30. Frevert J. Xeomin: an innovative new botulinum toxin type A. Eur J Neurol 2009; 16 Suppl. 2: 11-3

31. Eisele KH, Taylor HV, Bluemell J. Immunogenicity of NT 201 (Xeomin $\left.{ }^{\circledR}\right)$ in Cynomolgus monkeys following repeated, high dose injections [poster]. 44th Annual Interagency Botulism Research Coordinating Committee (IBRCC) Meeting; 2007 Oct 14-18; Asilomar (CA)

32. Jost WH, Blümel J, Grafe S. Botulinum neurotoxin type A free of complexing proteins $\left(\right.$ XEOMIN $^{\circledR}$ ) in focal dystonia. Drugs 2007; 67: 669-83

33. Frevert J, Dressler D. Complexing proteins in botulinum toxin type A drugs: a help or a hindrance? Biologics 2010; 4: 325-32
34. Electronic Medicines Compendium (eMC). XEOMIN ${ }^{\circledR} 50$ U: summary of product characteristics. 2011 [online]. Available from URL: http://medicines. org.uk/EMC/medicine/24582/SPC/Xeomin+50+Units/ [Accessed 2012 Feb 13]

35. Brin MF, Comella CL, Jankovic J, et al. Long-term treatment with botulinum toxin type A in cervical dystonia has low immunogenicity by mouse protection assay. Mov Disord 2008; 23: 1353-60

36. Minnasch P. Presence of neutralising antibodies in a patient population with cervical dystonia prior to clinical study entry [poster]. American Academy of Neurology Annual Meeting; 2010 Apr 10-17; Honolulu (HI)

37. Mohammadi B, Buhr N, Bigalke H, et al. A long-term follow-up of botulinum toxin A in cervical dystonia. Neurol Res 2009; 31: 463-6

38. Müller K, Mix E, Adib Saberi F, et al. Prevalence of neutralising antibodies in patients treated with botulinum toxin type A for spasticity. J Neural Transm 2009; 116: 579-85

39. Naumann M, Carruthers A, Carruthers J, et al. Meta-analysis of neutralizing antibody conversion with onabotulinumtoxinA (BOTOX ${ }^{\circledR}$ ) across multiple indications. Mov Disord 2010; 25: 2211-8

40. Truong D, Brodsky M, Lew M, et al. Long-term efficacy and safety of botulinum toxin type A (Dysport) in cervical dystonia. Parkinsonism Relat Disord 2010; $16: 316-23$

41. Greene P, Fahn S, Diamond B. Development of resistance to botulinum toxin type A in patients with torticollis. Mov Disord 1994; 9: 213-7

42. Herrmann J, Geth K, Mall V, et al. Clinical impact of antibody formation to botulinum toxin A in children. Ann Neurol 2004; 55: 732-5

43. Koman LA, Brashear A, Rosenfeld S, et al. Botulinum toxin type a neuromuscular blockade in the treatment of equinus foot deformity in cerebral palsy: a multicenter, open-label clinical trial. Pediatrics 2001; 108: 1062-71

44. European Medicines Agency (EMA). Guideline on immunogenicity assessment of biotechnology-derived therapeutic proteins [online]. Available from URL: www.ema.europa.eu/pdfs/human/biosimilar/1432706en.pdf [Accessed 2011 Jan 26]

45. Schulte-Baukloh H, Bigalke H, Miller K, et al. Botulinum neurotoxin type A in urology: antibodies as a cause of therapy failure. Int J Urol 2008; 15: 407-15

46. Kranz G, Sycha T, Voller B, et al. Neutralizing antibodies in dystonic patients who still respond well to botulinum toxin type A. Neurology 2008; 70: 133-6

47. Lange $\mathrm{O}$, Bigalke H, Dengler R, et al. Neutralizing antibodies and secondary therapy failure after treatment with botulinum toxin type A: much ado about nothing? Clin Neuropharmacol 2009; 32: 213-8

48. Shone C, Wilton-Smith P, Appleton N, et al. Monoclonal antibody-based immunoassay for type A Clostridium botulinum toxin is comparable to the mouse bioassay. Appl Environ Microbiol 1985; 50: 63-7

49. Dressler D, Dirnberger G. Botulinum toxin antibody testing: comparison between the immunoprecipitation assay and the mouse diaphragm assay. Eur Neurol 2001; 45: 257-60

50. Hanna PA, Jankovic J, Vincent A. Comparison of mouse bioassay and immunoprecipitation assay for botulinum toxin antibodies. J Neurol Neurosurg Psychiatry 1999; 66: 612-6

51. Palace J, Nairne A, Hyman N, et al. A radioimmuno-precipitation assay for antibodies to botulinum A. Neurology 1998; 50: 1463-6

52. Dressler D, Lange M, Bigalke H. Mouse diaphragm assay for detection of antibodies against botulinum toxin type B. Mov Disord 2005; 20: 1617-9

53. Rasetti-Escargueil C, Lui Y, Rigsby P, et al. Phrenic nerve-hemidiaphragm as a highly sensitive replacement assay for determination of functional botulinum toxin antibodies. Toxicon 2011; 57: 1008-16

54. Hatheway CH, Dang C. Immunogenicity of the neurotoxins of Clostridium botulinum. In: Jankovic J, Hallett M, editors. Therapy with botulinum toxin. New York (NY): Marcel Dekker, 1994: 93-107

55. Hamjian JA, Walker FO. Serial neurophysiological studies of intramuscular botulinum-A toxin in humans. Muscle Nerve 1994; 17: 1385-92 
56. Dressler D, Bigalke H, Rothwell JC. The sternocleidomastoid test: an in vivo assay to investigate botulinum toxin antibody formation in humans. J Neurol 2000; 247: 630-2

57. Birklein F, Erbguth F. Sudomotor testing discriminates between subjects with and without antibodies against botulinum toxin A: a preliminary observation. Mov Disord 2000; 15: 146-9

58. Botox $^{\circledR}$ : US prescribing information. Irvine (CA): Allergan, Inc., 2010

59. Dysport ${ }^{\circledR}$ : US prescribing information. Wrexham: Ipsen Biopharm, Ltd., 2010

60. BTXA ${ }^{\circledR}$ : Prescribing information. Gansu: Lanzhou Institute of Biological Products, 2011

61. Xeomin ${ }^{\circledR}$ : US prescribing information. Merz Pharmaceuticals GmbH [online] Available from URL: http://www.xeomin.com/Prescribing-InformationXeomin-26-Aug-2010.pdf [Accessed 2012 Feb 7]

62. Electronic Medicines Compendium (eMC). XEOMIN ${ }^{\circledR} 100 \mathrm{U}$ : summary of product characteristics, 2011 [online]. Available from URL: http://medicines.org.uk/ EMC/medicine/24582/SPC/Xeomin+100+Units/ [Accessed 2012 Feb 13]

63. Myobloc ${ }^{\circledR}$ : US prescribing information. San Francisco (CA): Solstice Neurosciences, Inc., 2009

64. Ranoux D, Gury C, Fondarai J, et al. Respective potencies of Botox and Dysport: a double blind, randomised, crossover study in cervical dystonia. J Neurol Neurosurg Psychiatry 2002; 72: 459-62

65. Chadda S, Tilden D, Jones D, et al. Cost effectiveness of Xeomin ${ }^{\circledR}$ in the management of cervical dystonia and blepharospasm. Eur J Hosp Pharm 2009; 15: 38-46
66. Marchetti A, Magar R, Findley L, et al. Retrospective evaluation of the dose of Dysport and BOTOX in the management of cervical dystonia and blepharospasm: the REAL DOSE study. Mov Disord 2005; 20: 937-44

67. Benecke R, Jost WH, Kanovsky P, et al. A new botulinum toxin type A free of complexing proteins for treatment of cervical dystonia. Neurology 2005; 64: 1949-51

68. Roggenkämper $\mathrm{P}$, Jost WH, Bihari K, et al. Efficacy and safety of a new Botulinum Toxin Type A free of complexing proteins in the treatment of blepharospasm. J Neural Transm 2006; 113: 303-12

69. Wohlfarth K, Müller C, Sassin I, et al. Neurophysiological double-blind trial of a botulinum neurotoxin type A free of complexing proteins. Clin Neuropharmacol 2007; 30: 86-94

70. Sesardic D. Is it possible to accurately determine content of botulinum neurotoxin type A in drug products? Drugs R D 2010; 10: 91-2

71. Pickett A. Consistent biochemical data are essential for comparability of botulinum toxin type A products. Drugs R D 2011; 11: 97-8

72. Sattler G, Callander MJ, Grablowitz D, et al. Noninferiority of incobotulinumtoxinA, free from complexing proteins, compared with another botulinum toxin type A in the treatment of glabellar frown lines. Dermatol Surg 2010; 36 Suppl. 4: 2146-54

Correspondence: Professor Reiner Benecke, Department of Neurology, University of Rostock, Gehlsheimer Strasse 20, 18147 Rostock, Germany.

E-mail: reiner.benecke@med.uni-rostock.de 